Özet:

Kullanıcı ihtiyaçlarının değişmesi sonucu mevcut geleneksel evler, çağdaş konfor şartlarını sağlamada yetersiz kalmış, sahipleri tarafından terk edilmiş veya kiraya verilmiştir. Bu işlevsel eskimeyle gelenêksel Diyarbakır evleri, kırdan kente gelen, geçimini tarım ve hayvancılığa dayalı iş kollarından sağlamış fakat kente gelince doğal olarak herhangi bir gelire sahip olamamış insanların yerleşim mekanı olmuştur. İşlevsel eskimenin yanında fiziksel ve toplumsal nedenlerle de geleneksel evlerde meydana gelen değişimler kültürel mirasın geleceğe aktarılmasında ciddi sorunlar oluşturmaktadır.

Bu çalışmanın amacı, Suriçi bölgesinde yer alan geleneksel Diyarbakır evlerini, plan düzenlemeleri, cephe oluşumları, malzeme ve yapım tekniği açısından analiz ederek değerlendirmektir. Kentsel sit alanındaki geleneksel evleri tehdit eden sorunlar ortaya konularak koruma için çözüm önerileri getirilmiştir. Bölge halkının daha modern yaşam şartlarına kavuşturulması hedeflenirken kültürel mirasın yaşatılması da sağlanacaktır.

\section{Summary}

The traditional houses which are inadequate to provide the contemporary comfort conditions because of the changes in user requirements abandoned by the owners or rented. With this functional alteration, the traditional Diyarbakur houses have become home to the people who moved from rural areas and who had earned their living from agriculture but after moving to the city, naturally become unemployed. Together with this functional alteration, changes which took place in traditional houses due to physical and social reasons results in

serious problems in transferring of cultural heritage to the future.

The aim of this paper is to evaluate the Diyarbakır houses in Surici region by analyzing plan organization of structures, elevations, materials and construction techniques.

Solution proposals are given for conservation by bringing out the problems threatening historical houses in historical site. While providing modern lifestyle conditions to local people the cultural heritage will be conserved as well. Anahtar kelimeler: Geleneksel evler, sürdürülebilirlik, bozulmalar, koruma önerileri

Keywords: Traditional houses, sustainability, deterioration, conservation proposals

\title{
Diyarbakır Suriçi Geleneksel Evlerinde Koruma Sorunlari ve Çözüm Önerileri
}

Yrd. Doç. Dr. Mücahit Yıldırım Dicle Üniversitesi Müh-Mim. Fakültesi, Mimarlık Bölümü

\section{Giriş}

Diyarbakır Suriçi bölgesinde, hızla değişen şehirleşme hareketleri ve kırdan kente yaşanan göçün etkisiyle geleneksel evlerde büyük bir tahribat görülmektedir. Bu çalışmayla, geleneksel Diyarbakır evlerini tehdit eden fiziksel ve sosyal etkenler ortaya konularak, bu sorunların çözümüne yönelik önerilerin getirilmesi amaçlanmıştır. Diyarbakır evleri için geliştirilen koruma önerileri; sosyoekonomik, kültürel ve yapısal değerlendirmelerden oluşmaktadır.

\section{Tarihi Bölgenin Tanımı}

Karacadağ'dan Dicle Nehri'ne uzanan $650 \mathrm{~m}$. yükseklikteki geniş bazalt platosunun doğu kenarında kurulmuş olan kent, Dicle Vadisi'nden 100 m. kadar yüksekte yer alır (Gabriel, 1940, 90). Herakles, Firat Nehri üzerinde salların oluşturduğu köprüye ulaşan gezisine eski adı Amida olan Diyarbakır'dan başladığını anlatır (Ramsay, 1962, 311). Geleneksel ve sivil mimarlık örneklerinin oldukça yoğun bir şekilde yer aldığı bölgede geleneksel, organik sokak dokusu fazla bozulmadan günümüze kadar gelebilmiştir. Kırdan kent yaşamına göç sebebiyle yaşanan yapısal ve sosyal tahribat tarihi Suriçi bölgesini kültürel bir bozulmaya maruz bırakmıştır. Göç eden insanların yerleşmeyi tercih ettikleri bölge olması nedeniyle Suriçi, imar kuralarına göre inşa edilmemiş, yüksek katlı, kalitesiz binalarla doludur. Gelişmekte olan bir kent görüntüsü taşıyan Diyarbakır kenti, sosyal farklılıklar nedeniyle düşük nitelikli bir yaşama çevresi karakterindedir.

\section{Şehir Dokusu}

Kentin ve surlarının ilk kuruluş tarihi bilinmemekle beraber A. Gabriel'e göre İçkale bölgesi kentin ilk yerleşim alanıdır (Gabriel, 1940, 151). Tarihi kentin strüktürünü belirleyen en önemli kentsel eleman surlar olmuştur (Şekill).

Helenistik ve Roma şehircilik ilkeleriyle düzenlenmiş birbirini dik kesen yollar Bizans döneminde değişikliğe uğramıştır (Can, 1991, s.117). 
Diyarbakır kenti, Suriçinde gelişmek zorunda kalmış, iklimin de etkisiyle sokaklar daralmış, evler bitişik olarak inşa edilmiştir. Sokaklarda, yazın sıcă̆ından korunmak amaciyla, ahşap kirişlerin dar sokakta karşısındaki parsele geçerek üstte bir oda oluşturduğu kabaltılar bulunur.

\section{Evlerin Mimari Tasarım $\ddot{O}_{\text {zellikleri }}$}

Geleneksel evler, Anadolu'nun değişik bölgelerinde değişik fiziksel görünümdedirler (Sezgin, 1981, 28). 12. ve 13.yüzyıllarda Güneydoğu Anadolu Bölgesi mimarisi, sıkı politik ve kültürel ilişkiler nedeniyle Irak ve Suriye mimarisinin etkisi altında kalmıştır (Kuban, 1995, 229). Geleneksel Diyarbakır evlerinde su, gölge ve yarı açık alanlar tasarımda etkin rol oynar. Havuzlu eyvan, su kanalları, zemine yarı gömülü bodrum (Mezopotamya serdabı) sıcak iklimin önceliklerini oluşturur. Anadolu Türk evinin gelişiminde İslam dininin etkisi de görülür. İçe dönük bir yaşantı şekliyle dış ilişkiler kısıtlı hale getirilmiştir.

Kışlık bölümler genelde tek katlı olup kuzeyde yer alır ve güneye bakar. Odada isınmak için ocak yer almaz. Bunun yerine köz haline gelmiş meşe kömürü mangalla içeriye alınır (Tuncer, 1999, 42).

Evin tek ocağı mutfakta yer alır ve evin kış odası da mutfağa yakındır. Kışlık odanın döşemesi horasan harcının sıkıştırılmasıyla oluşturulur. Genelde kış odaları dışında güneye pencere açılmaz. Dört mevsimde kullanılan kısımlar ise doğu ve batıya yönlendirilir.

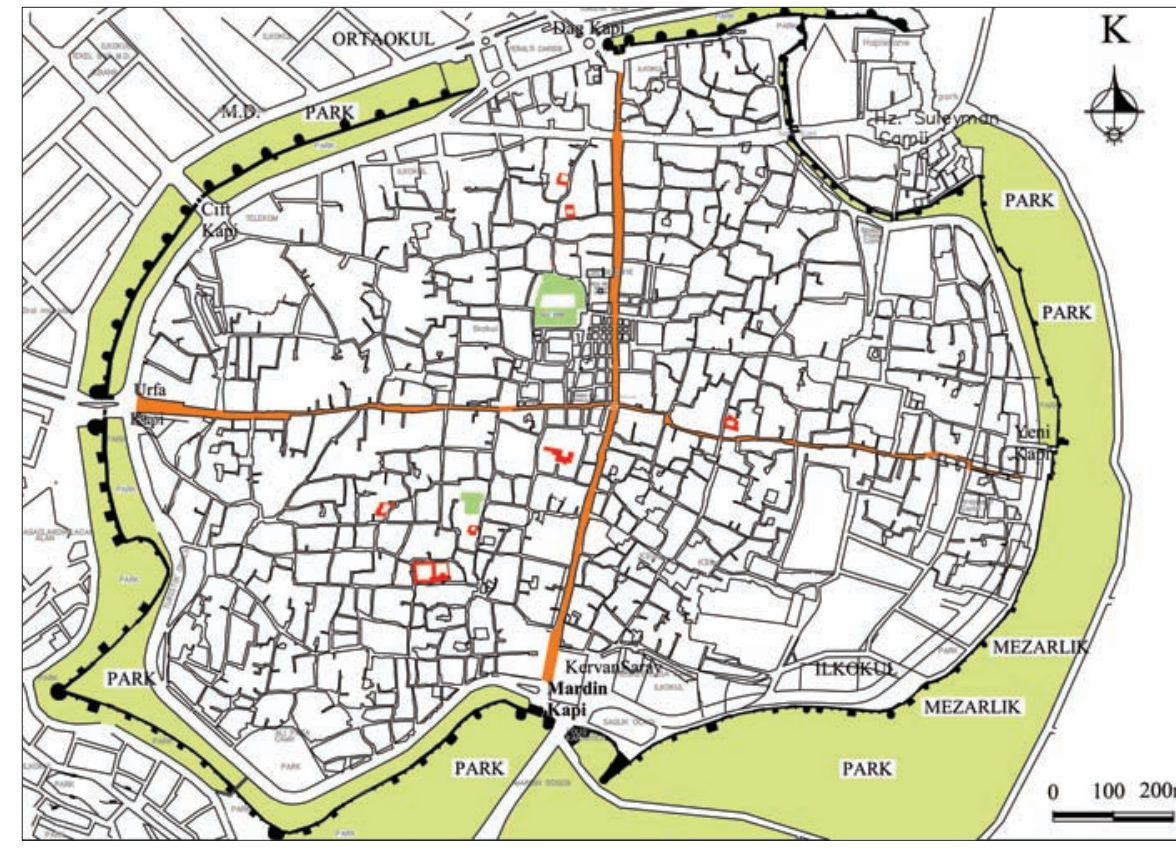

İklimin etkisi kütlelerin, güneşin yönüne göre avlu çevresinde; yazlık, kışlık olarak dizilişlerinde kendini gösterir (Ş̧ekil 2).

Geleneksel Diyarbakır evlerinde en çok oturulan mekan üç tarafı kapalı, büyük
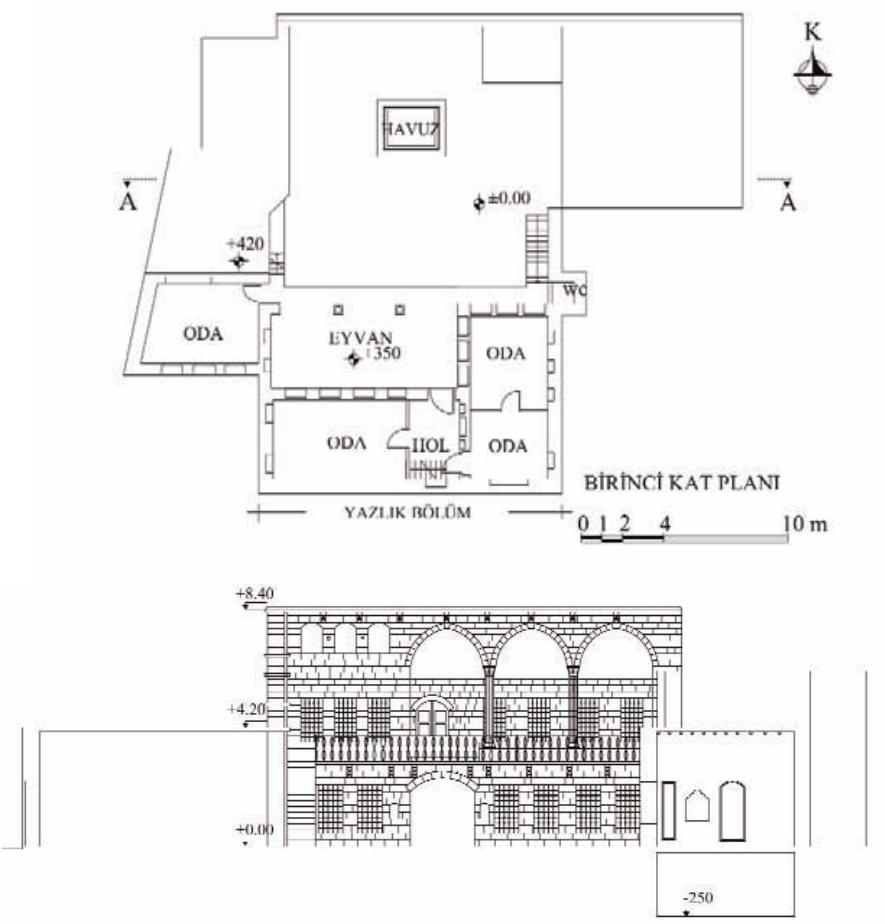

$\Lambda \Lambda$ KESITT GÖRÜNÜS
Şekil: I

Diyarbakır Suriçi haritası, şehir surlarinin etrafindaki kaçak yapılar 2002 yilında temizlenerek yeşil bir kuşak oluşturulmuştur.

(M. Yıldırım) Şekil: $2 a$ Behram Paşa Konağı zemin kat planı

(M. Yildirim, 2002) Şekil: 26 Behram Paşa Konağı kesit görünüşü

(M. Yıldırım, 2002)

88 Sayıs Aralık 2006 


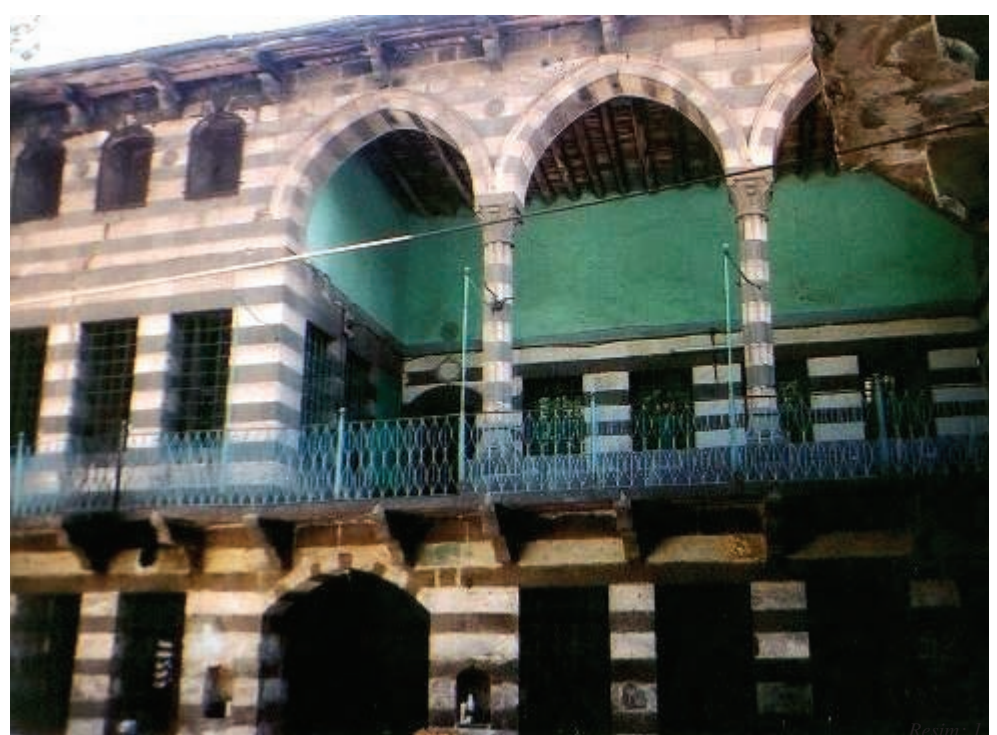

Resim: I

Behram Paşa Konă̆ı üf kemerli eyvanı

şekil: $3 a$

inönü Mahallesi

Manav Sokak, no:I

(M. Yildirım, 2002)

Şekil: 36

Inönü Mahallesi, Manav

sokak I nolu evin avludan

görünüşü. Birinci katta yer

alan eyvan ahşap

doğramayla kapatılmıs.

Üste fatı yapılarak bir

cihannüma köşkü

eklenmiştir.

(M. Yildirım, 2002)

Resim: 2

Manav Sokak, I nolu ev. kemer veya kemerlerle avluya açılan “eyvandır”. Tek, iki, veya üç gözlü olarak inşa edilirler. Üst katta da yer alabilen eyvanlar yazın ev halkının yaşamını sürdürdüğü mekanlardır (Resim 1).

$\mathrm{Bu}$ ortak mekan yapı içinde eşdeğer odaların doğrudan açıldığı bir ortak kullanım alanı, toplumsal bir odaktır (Arel, 1982, 25). Eyvanlı ev Güneydoğu Anadolu'da simetrik biçimli bir yapıdır (Akın,1984, 40). Eyvanın bir özelliği de açık alan avlu ile kapalı alanlar arasında yarı açık bir geçiş elemanı olmasıdır.

Avlu seviyesinde yer alabilen bu mekana bazen de basamakla çıkılır. Eyvanların üst örtüleri kavak kirişli dam veya nadiren
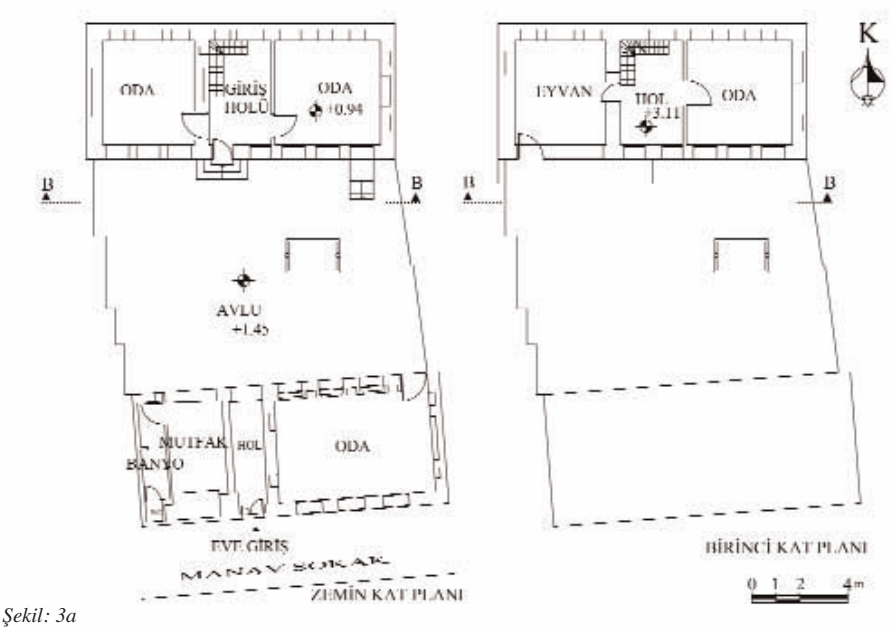

Şekil: $3 a$

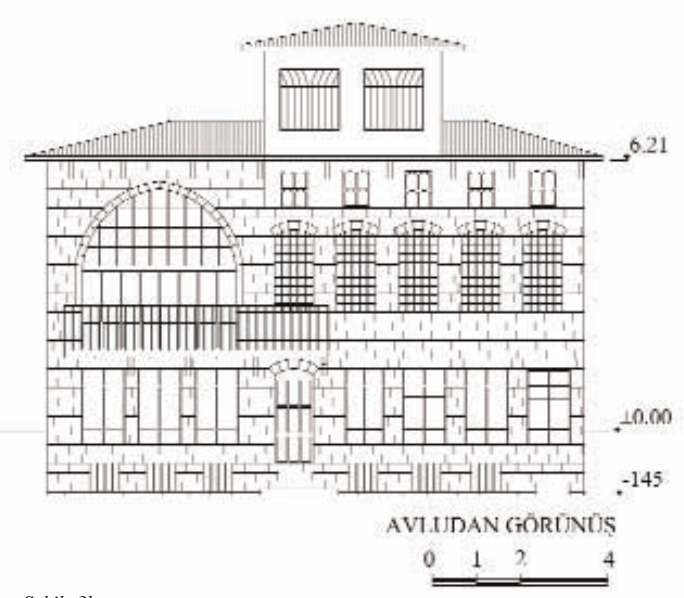

Şekil: $3 b$

tonozdur. Mutfak, avluya açılan bir mekandır. Aile yapısının büyüklüğü evlerin büyüklüğünü ve avlu çevresindeki kütlelerin sayısını belirlemiştir (Şekil 3, Resim 2).

\section{Yapım Tekniği ve Malzeme}

Yörede bulunan taş malzeme bazalt, geleneksel evlerin şekillenmesinde rol oynar. Kat yükseklikleri 3-4,5 m. arasında değişiklik gösterir. Sokağa bakan avlu duvarı, moloz taş örgüyle biçimlenirken avlu cephesi genellikle bazalt taşının ince yonu olarak işlenmesiyle oluşturulur (Resim 3). Derz etkisi verebilmek amaciyla

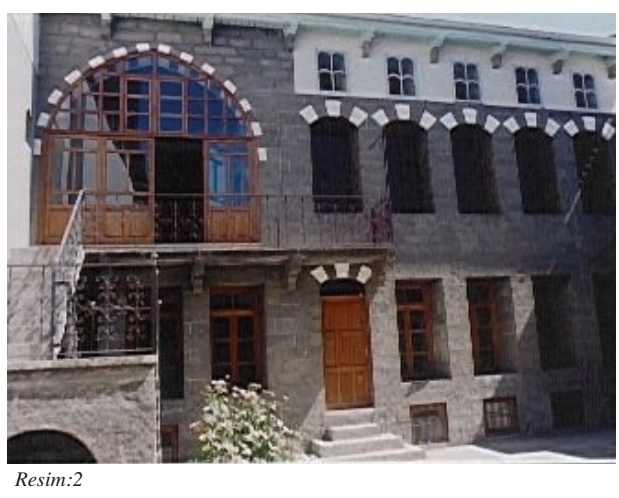

arada kireç kaymağına yumurta akı katılmasıyla oluşturulan ve cas adı verilen harç kullanılır (Tuncer, 1999,62).

Taş mimarinin taşıyıcı sistem elemanlarından kemerler, geleneksel Diyarbakır ev mimarisinde oldukça 


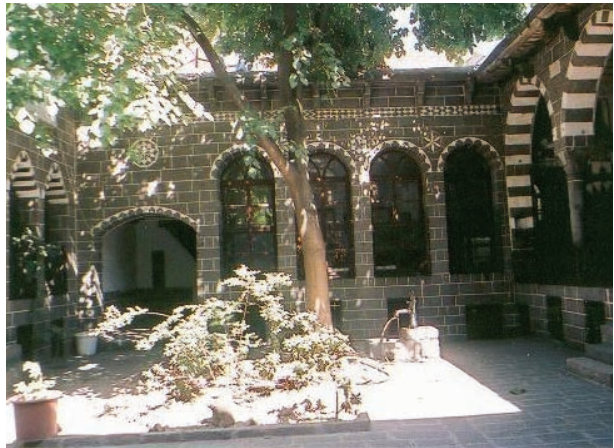

Resim: 3

zengin bir biçimde kullanılmıştır (Şekil 4-5).

Boyu 4-4.5 m. yi geçmeyen ahşap tavan kirişleri odanın kısa kenarı doğrultusunda, yastık kirişleri üzerine oturtulur. Üstü tahta ile kaplanır ve bunun üzerine ince ve kaba yonga, hasır veya saz serilir. $15-20 \mathrm{~cm}$. toprak serildikten sonra iyice sulanarak loğlanır.

Geleneksel Diyarbakır evlerinde kullanılan bazalt, siyah renkli, homojen yapılı ve ağır, püskürük bir taştır. Bazaltın yanında almaşık olarak kireç taşı kullanılır.

\section{Evleri Tehdit Eden Etkenler}

Uzun yıllar boyunca kullanılarak yaşatılan geleneksel evlerde, değişime bağlı olarak çeşitli bozulmalar görülmektedir.

$\mathrm{Bu}$ bozulmaları toplumsal ve fiziksel nedenlere bağlı olarak değerlendirmek mümkündür. Ataerkil aile tipinin yerini çekirdek aileye bırakmasıyla, birlikte bir yaşam için planlanan geleneksel evler modern yaşamın ihtiyacına cevap veremeyecek duruma gelmiştir.

Aile yapısındaki değişimle birlikte yapı-konfor gereksinimi de değişikliğe uğramış, çağdaş dünyanın gerektirdiği ihtiyaçların karşılanamaması sonucu Anadolu'nun diğer bölgelerinde olduğu gibi geleneksel Diyarbakır evleri de sahipleri tarafindan terk edilmek durumunda kalmıștır (Resim 4).

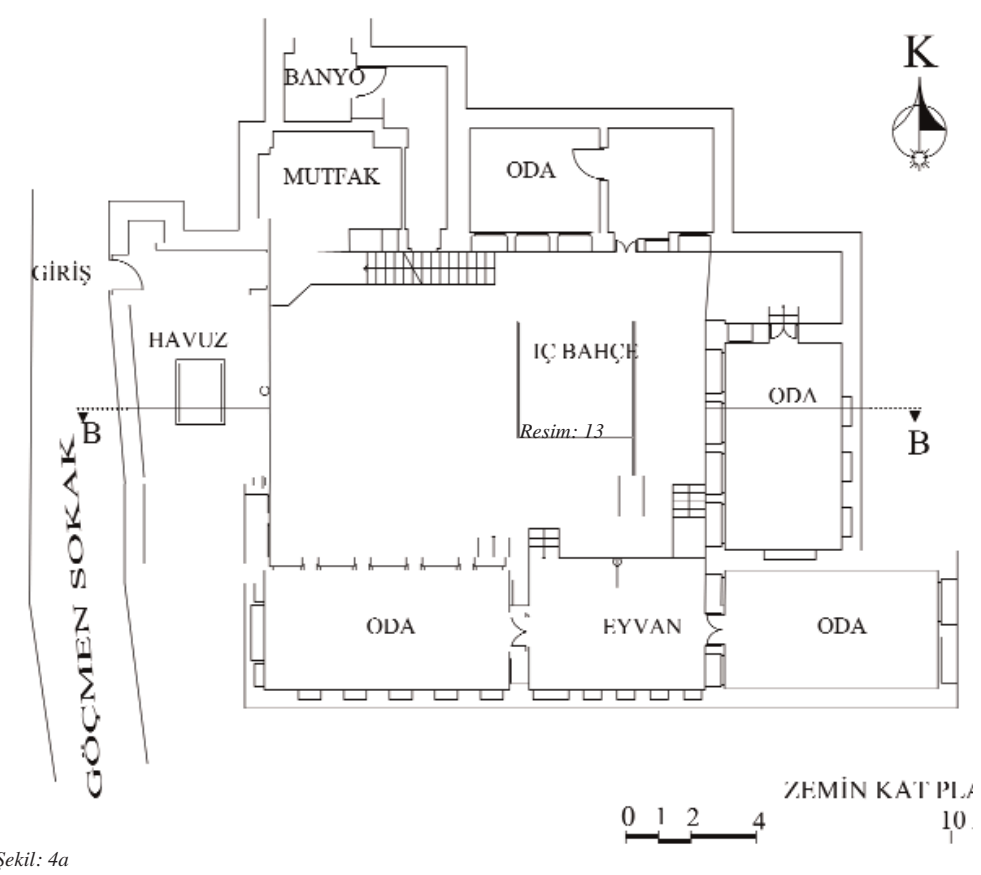

Şekil: $4 a$

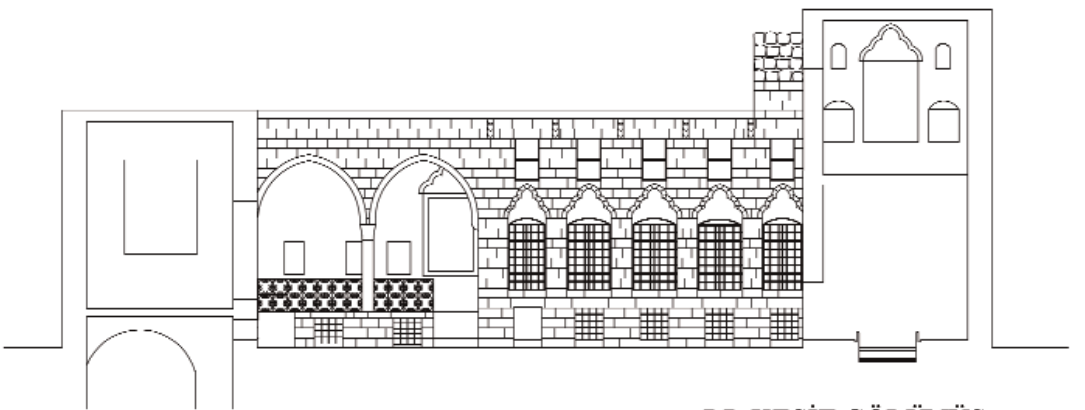

BB KESITT GÖRÜNÜŞ

Şekil: $4 b$

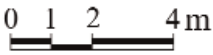

Eskiden bir ailenin oturduğu evlere

birden fazla aile yerleşmiștir.

Ekonomik güçlükler içerisinde bulunan kullanıcıların, kendilerine özgü yaşam tarzlarına uygun olarak gerçekleştirdikleri bazı değişiklikler, yapılarda bozulmalara neden olmaktadır.

Mekanların özgün kullanımlarına aykırı ve kullanıcı ihtiyaçlarının çeşitlenmesine bağlı olarak, farklı amaçlar için kullanımları, Suriçi geleneksel evlerinde yaygın olarak görülmektedir. Üst katlarda yer alan bazı eyvanlar, pencere doğramalarıyla kapatılarak, kapalı bir mekan haline getirilmiştir.
Sekil: $4 a$ Esma Ocak Evi zemin kat planı (M. Yildirım, 2002) Şekil: 46

Esma Ocak Evi avludan güney görünüşü (M. Yildırım, 2002) Resim: 3 Esma Ocak Evi avlu görüntüsü 

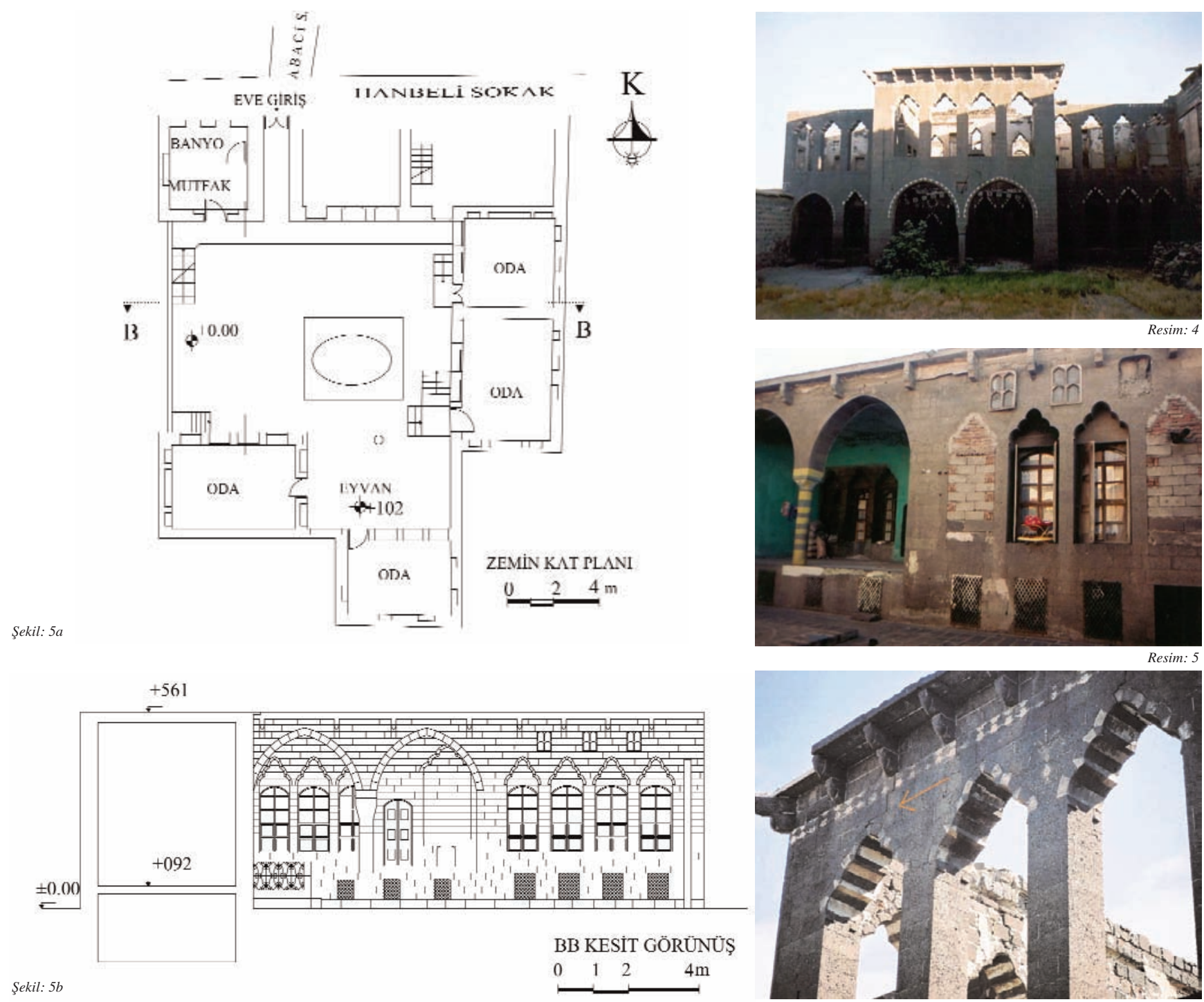

Şekil: sa Ali Paşa Mahallesi Hanbeli Sokak 5 nolu evin planı

(M. Yildirım, 2002) şekil: 56

Hanbeli Sokak 5 nolu evin BB kesit görünüşü

(M. YIldirım, 2002)

Resim: 4

Cemil Paşa Konağı

selamlık bölümü

terkedilmis durumda

Resim: 5

Hanbeli Sokak s nolu evde cephe bozulmaları.

Resim: 6

Cemil Paşa Konağı hasarlı selamlık bölümü
Yiyeceklerin serin bir yerde tutulmasını amaçlayan yarı gömülü bodrum katları, pencere boşluklarına duvar örülerek kapalı birer depo haline getirilmiştir. Bodrum kat pencere boşluklarının kapatılması cephe düzenini etkilemiştir. Avluya bakan bazı pencerelere duvar örülmüsşür (Resim 5). Avluda konsol taşlarına oturan birinci kat taş plak çıkmaları, betonarme plağa çevrilmiştir. Periyodik bakımının zorluğuna bağlı olarak, ahşap kirişlemeli toprak dam örtü kaldırılarak, yerine betonarme plak döşeme yapılmıştır.
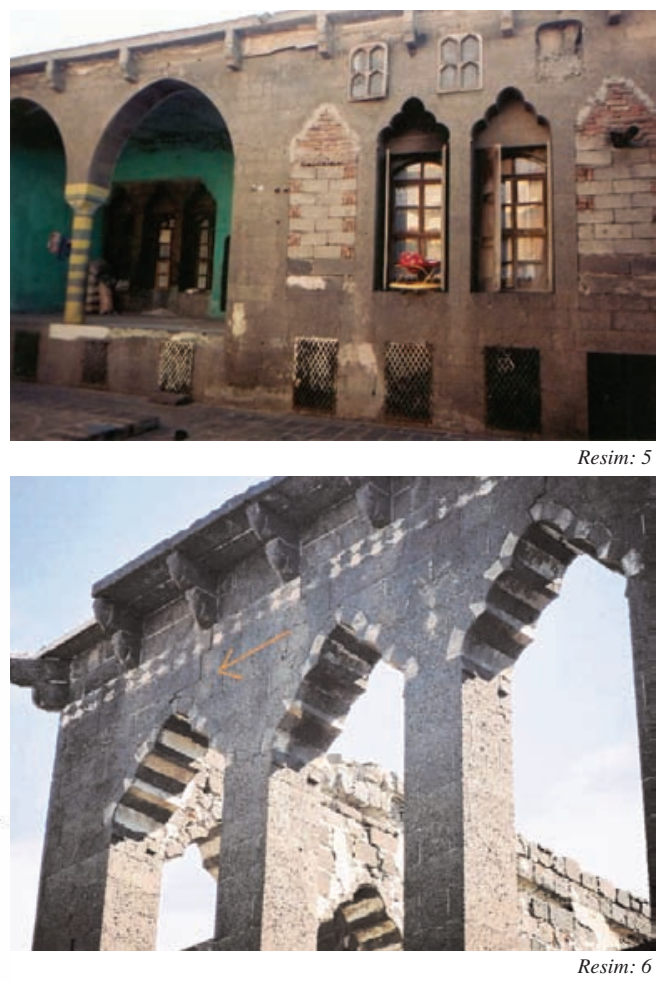

Yapı malzemesinin güneş radyasyonuna maruz kalması termal etkiye yol açmaktadır (Feilden, 1997, 99). Sicak-kuru bir iklime sahip kentte, siyah ve mat bir malzeme olan bazaltla yapılmış geleneksel evlerde termal genleşmeye bağlı tahribat oluşabilmektedir. Yapıda en büyük sorun üst yapıda suya bağlı olarak kendini göstermekte, toprak damların sızdırmasıyla taşlarda ayrışma ve çatlamalar oluşabilmektedir (Resim 6).

Ahşap kirişlemeli döşemelerin yerini betonarme döşemenin alması, üste ek kat 
çıkılması, ve ek olarak yapılan merdivenler aşırı yüklenmeyi de beraberinde getirmekte, tahribatı arttırmaktadır. Ev yapım ustalarının sayısı azalmakta, kimse bu mesleği geliri düşük diye seçmemektedir.

\section{Evlerin Korunmasına Yönelik Öneriler}

Taşçılık zanaatı gelirinin ve iş sahasının az olması nedeniyle yok olmakla karşı karşıyadır. Bu daldaki kalifiye insan eksikliği nedeniyle tarihi yapılar gerektiği gibi onarılamamaktadır. Yapılan bilinçsiz, acemice onarımlarla geri dönüşü olmayan yanlışlıklar yapılmaktadır.

Evlerde bugünün kullanıcı ihtiyaçlarının değerlendirilmesi sonucunda bazı eklemelerin, tamamlamaların yapılması zorunlu olacaktır.

Kullanıcı gereksinmelerine bağlı olarak, avluya cephesi açık olan mutfakların gerek hijyen şartlarını sağlamak ve gerekse kışın soğuğundan korumak için hafif, sökülebilir bir yapı elemanı ile kapatılması uygun olacaktır. Mutfak, tezgah ve dolap ilavesiyle çağdaş kullanıma uygun hale getirilmelidir. Geleneksel Diyarbakır evlerinde; tuvalet, banyo ve bunların tesisatları için duvarlarda ve döşemelerde mevcut elemanların elden geçirilmesi, sağlamlaştırılması gerekecektir. Avlu köşesinde, giriş yakınında eklenti halinde duran tuvalet ve banyolar evin içine alınmalıdır. Elektrik tesisatı yenilenirken görsel kirliliğe ve yapının tahribatına sebep olabilecek uygulamalardan kaçınılmalıdır. Evlerde 1sıtma sistemi hala kullanımda olan sobalarla devam ettirilebilir. Bu yöntem ucuz olması sebebiyle tercih edilmektedir. Ancak sosyal kültürel hizmet binası olarak kullanılabilecek bazı büyük evlerde merkezi ısıtma kullanılmalıdır.
Geleneksel evlere eklenti yapılmasına izin verilmemeli, evlerin üstlerine veya avlunun bir köşesine yapılan eklentiler kaldırılmalıdır. Yağmur ve kar suları, periyodik bakımı çoğu zaman yapılmayan toprak damdan içeri girerek üst sıradaki taşlarda ayrışma ve erimelere sebep olmaktadır. Toprak damlar onarılırken; üst örtüyü oluşturan toprak tabakası kaldırılmalı, kavak kirişleri ve üstündeki kaplama tahtalarının duvara oturan başları emprenye edilmelidir. Ahşap kaplama tahtasının üzerine su yalıtımı yapıldıktan sonra katkı1ı toprak tabakası serilmelidir.

\section{Sonuç}

Suriçinde yaya ve araç yollarının yeniden belirlenmesi, tarihi bölgedeki araç baskısının azalmasını sağlayacak, burayı yayalar için bir cazibe merkezi haline getirecektir.

Kültürel mirası gelecek kuşaklara aktarmanın en etkili yollarından biri; kullanıcıların korumaya katılımını sağlamaktır. Kullanıcı grupları için koruma uygulamalarının yanı sıra belirli zamanlarda meslek eğitimine yönelik teorik dersler de verilmelidir. Yok olmaya yüz tutmuş geleneksel sanatlarımızın yaşatılması için bu oldukça önemlidir. Ataerkil düzen içerisinde gerçekleştirilmiş büyük bazı evlerin yeniden ev olarak bir bütün halinde kullanılmaları zordur. Bu nedenle bu yapılara, ev olarak kullanım dışında başka fonksiyonlar vermek gerekmektedir. Bu şekilde tarihi bölgenin ihtiyacı olan bazı sosyal donatılar da mevcut yapılarda çözümlenecektir. $\mathrm{Bu}$ sosyal donatılar, el sanatları üretimi ve el sanatları ürünlerinin satışı, hediyelik eşya üretimi ve bu tür eşyaların satışı, çocuk rehabilitasyon merkezi ve gençlik merkezleridir (Resim 7). Evlerin büyük bir çoğunluğu ise "yine ev" olarak kullanılmalıdır. 


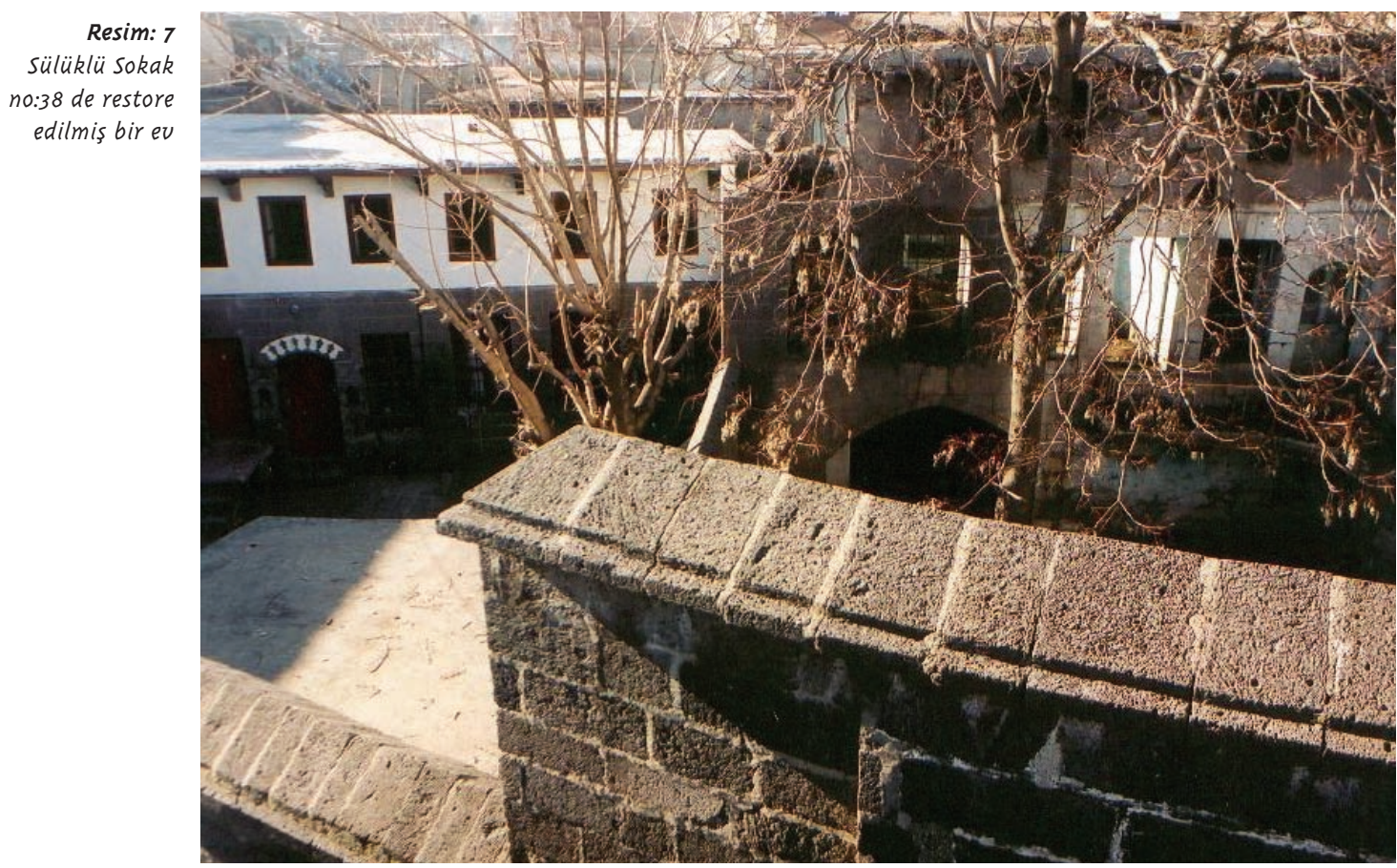

Tarihi Suriçi bölgesinin koruma altına alınarak sağlıklılaştırılması için etkin bir organizasyonu sağlayacak bir ekibin oluşturulması gerekmektedir. Gerekli kaynağın sağlanması ve planlamadan uygulamaya kadar geçen süreçte karşılaşılan tüm sorunları çözme yetkisine sahip olacak olan bu ekip; kredileri yönlendirmede, restorasyon uygulamalarında, kullanıcı katılımını sağlamada, malzeme, teknik hizmet ve eğitim verme konularında etkin olacaktır. Halkın görüşü alınmalı ve bu konuda fikir sahibi edilerek korumaya etkin olarak katılımı s ağlanmalıdır. Koruma bilinci basın yayın yoluyla halkın tüm kesimine ulaştırılmalı, koruma uygulamalarının nasıl yapılacağına dair el kitapları ve broşürler basılarak dağıtılmalıdır. $\mathrm{Bu}$ amaçla yerel yönetimler kanalıyla eğitim kursları açılmalıdır $\bullet$ 


\section{KAYNAKÇA}

Akın, Günkut, 1984. Doğu ve Güneydoğu Anadolu'daki Tarihsel ev Tiplerinde Anlam, Doktora Tezi, İstanbul: İstanbul Teknik Üniversitesi, s.40.

Arel, Ayda. 1982. Osmanlı Konut Geleneğinde Tarihsel Sorunlar. İzmir: Ege Üniversitesi.

Beysanoğlu, Şevket. 1997. Anıtlanı ve Kitabeleri İle Diyarbakır Tarihi. v.1. Ankara: Diyarbakır Büyükşehir Belediyesi.

Binan, Ulusoy, Demet. 1993. Güzelyurt Örneğinde Kapadokya Bölgesi Yığma Taş Konut Mimarisinin Korunması İçin Bir Yöntem Araştırması. Yayımlanmış Doktora Tezi, İstan bul: Yıldız Teknik Üniversitesi. s.82.

Can, Cengiz, 1991. Diyarbakır Tarihi Çevre Değerlerinin Kronolojik Yerleşmesi ve Şehir Strüktürü, Diyarbakır'ı Tanıtan Adam Yazar Şevket Beysanoğlu'na 70. Yaş Armağanı, Ankara: Ziya Gökalp Derneği Yayını.

Erginbaş, Doğan. 1953. Diyarbakır Evleri. Yayımlanmış Doçentlik Tezi. İstanbul: İstanbul Teknik Üniversitesi.

Feilden, M. Bernard. 1997. Conservation of Historic Buildings. Suffolk. St. Edmundsbury Press Ltd.

Gabriel, Albert. 1940. Voyages Archeologiques dans La Turquie Orientale. Paris. Institut Français D’Archeologie De Stamboul.

Kuban, Doğan. 1995. Türk Hayatlı Evi. İstanbul: Eren Yayıncilık.

Ramsay, W.M. 1962. The Historical Geography of Asia Minor. Amsterdam: Hakkert-Publisher.

Sezgin, Haluk. 1981. Anadolu Türk Vernaküler Mimarisinin Yayılma ve Etki Alanları. Akademi 10 Mimarlık ve Sanat Dergisi, s. 28.

Tuncer, Orhan, Cezmi.1999. Diyarbakır Evleri. Ankara: Diyarbakır Büyükşehir Belediyesi Yayınları.

Yıldırım, Mücahit, 2002. Geleneksel Diyarbakır Evlerinin Korunmasına İlişkin Bir Yöntem Araştırması, İstanbul: Mimar Sinan Üniversitesi, Doktora Tezi. 